\title{
The Influence of Good Corporate Governance and Corporate Social Responsibility on Firm Value: Evidence from Indonesia
}

\author{
Farida Farida* \\ Faculty of Economics and Business, Persada Indonesia YAI University, Jakarta, Indonesia \\ Adhika Ramadhan \\ Faculty of Economics and Business, Persada Indonesia YAI University, Jakarta, Indonesia \\ Ratih Wijayanti \\ Faculty of Economics and Business, Persada Indonesia YAI University, Jakarta, Indonesia
}

\begin{abstract}
The company goal is to maximize the shareholders' prosperity, not just to maximize profit. The fact is that the company not only has economic responsibility but also social responsibility to the community and its environment. The purpose of this study was to analyze the effect of good corporate governance (GCG) and corporate social responsibility (CSR) on the firm value. The research sample of 15 companies was taken using purposive sampling from companies listed in the LQ-45 on the Indonesia Stock Exchange for the period of 2014-2017. This study uses panel data regression analysis with Random Effect model method. GCG is a representation of managerial ownership, institutional ownership, independent commissioner, and audit committee. The results of this study indicate that there is a significant influence between GCG and CSR on firm value simultaneously. Partially, independent Commissioners and CSR each have an influence on the firm value, but there is an anomaly.
\end{abstract}

Keywords: GCG; CSR; Firm value; LQ-45.

(9) (9) CC BY: Creative Commons Attribution License 4.0

\section{Introduction}

The company is established with a clear goal, which is to maximize the value of the company. The company's goal is to maximize the shareholders' prosperity, not just to maximize profit. Short-term oriented companies only prioritize maximum profits, without regard to social responsibility and ignoring risks. The fact that cannot be ignored is CSR which is currently no longer an option, but has become a fasionable management concept (Türker, 2015).

To realize the company's goals requires a new awareness, that the company not only has economic responsibility (especially to shareholders) but also has social responsibility to the community and its environment. With an awareness of the social environment of this community, the concept of corporate social responsibility (CSR) emerged. Exploitively exploiting natural resources so far threatens the sustainability of raw material resources and energy (Iwuji et al., 2016), and triggers social disharmony with the environment community and increasingly severe labor conflicts. Therefore, it can be said that CSR plays an important role in sustainable development (Behringer and Szegedi, 2016).

Research on corporate social responsibility towards corporate value is mostly done in Indonesia and in other countries. A survey released by the National Consumers League and Fleishman Hillard International Comunication shows that two-thirds of consumers will prefer to buy company products that they are socially responsible for, especially companies that treat their employees well (Iwu-Egwuonwu, 2010). So that it can be understood that corporate social responsibility plays an important role in increasing company value (Jo and Harjoto, 2011; Kang et $a l ., 2015)$ and become a determining factor for consumer choice (Modak et al., 2014). However, CSR activities are not able to maximize the value of the company, instead causing a significant reduction in stock prices when imposing CSR through regulation (Manchiraju and Rajgopal, 2015)

CSR activities are carried out only possible if the company implements good corporate governance / GCG (Cahyandito and Pau, 2017). With good governance, trust will be obtained from investors, customers and the wider community (Sarah, 2017). Long-term goals are expected to increase the value of the company.

In the process of maximizing the value of the company there will be differences in interests between shareholders and managers. These differences have led rise a theory known as the agency conflict (Panda and Leepsa, 2017). This conflict often raises c osts which are called agency costs, such as changes in share ownership structure between management and stockholders.

Shareholders have an interest in supervising management performance as a function of good corporate governance (GCG), while, there is also independent supervision which is the duty of the independent board of directors to prevent agency problems or to align between managers and shareholders.

The supervisory process for management performance can also be carried out by a board of directors who, in addition to being responsible for monitoring, is also responsible for the management of the company's resources and operations. Supervision can also be carried out by the audit committee to ensure transparency and accountability of 
the financial management report. Those parties which are able to reduce management actions that can be detrimental as a form of GCG implementation.

Based on this background, the purpose of this study was to analyze the influence of good corporate governance and corporate social responsibility on the firm value that included in the LQ-45 on the Indonesia Stock Exchange in the period of 2014-2017.

\section{Literature Review}

\subsection{Firm Value}

Corporate actions are often carried out such as going public, mergers, acquisition, even when the closure of a business requires an assessment of the company's assets. Firm value measurement generally uses the company's stock price, as in research (Jallo et al., 2017; Mulyono et al., 2018; Pandelaki and Farida, 2017) which reflects the higher share price means the higher the value of the company. However, there is also a measure of corporate value is market price to book value (PBV) conducted by Dagilienè (2013), Hadiwijaya et al. (2016), Hafez (2016), as well as the industry-adjusted Tobin's Q method (Almaqoushi and Powell, 2017; Gherghina and Vintila, 2016), and approximate Tobin's Q (Chan and Li, 2008; Fahlenbrach and Stulz, 2009; Kurniasari et al., 2017; Ruiz-Mallorquí and Santana-Martín, 2011; Vania and Supatmi, 2014).

Research conducted byHaryono and Iskandar (2015), Ruiz-Mallorquí and Santana-Martín (2011) used Tobin's $\mathrm{Q}$ and PBV to measure company value. Tobin's Q is the equity market value plus long-term debt then divided by total assets (Hatem, 2015). Market to book value ratio that reflects the company's value in the Hafez (2016) is the ratio between the current stock market and book value.

\subsection{Agency Theory}

Agency theory is based on contractual relations amongs members within existing companies, principals and agents as the main actors (Daly, 2015). Shareholders entrust managers the authority to make decisions. Managers are as the decision maker sometimes have interests for themselves and ignore the interests of shareholders. This deviates from company goals. Agency theory, can explain how the parties involved in the company will behave, because basically between agents and principals have different interests which can lead to conflict.

The existence of agency problems raises agency costs (Jensen and Meckling, 1976). These costs include monitoring costs, bounding costs, and the cost of losses due to a decrease in the level of utility (the residual loss). This agency theory is the basis of the corporate governance concept. Corporate governance aims to reduce agency costs due to information asymmetric (Juniarti, 2013). How sure investors are to invest, it depends on how the corporate governance is implemented to gain profits. Hence investors have an interest in controlling managers (Shleifer and Vishny, 1997).

\subsection{Good Corporate Governance (GCG)}

Corporate governance is a set of methods, rules, structures and processes of managed company activities (Khan, 2011) to achieve a balance between the interests of the organization and stakeholders (Jaimes-Valdez et al., 2017). Khan (2011), in his review said that for long-term corporate governance will increase value for shareholders and companies. There is no single definition of corporate governance.

Corporate governance consists of institutional ownership variables, independent directors, and audit committee (Willim, 2015). Research (Juniarti, 2013) GCG variable is a proxy of ownership structure, board of directors and audit committee. Unlike GCG in banks, Bank of Indonesia sets the main principles in GCG that are related to transparency, accountability, responsibility, independence and fairness (Hadiwijaya et al., 2016). Research conducted by Ilyas and Rafiq (2012), used a measure of governance in the banking sector consisting of discipline, social awareness, accountability, fairness and responsibility. The global financial crisis is one example of failure in corporate governance (Kumar, 2013). The research conducted by Vania and Supatmi (2014) presented that corporate governance as a board diversity measured by five variables, namely women in board, competence in the economy and business, age, external director and citizenship. In Indonesia, the owner is generally as management as well. Likewise the director is also a commissioner, so the monitoring and control function is not independent (Hidayat and Utama, 2015)

Managerial ownership is also widely used as a proxy in corporate governance variable as in research by Chen (2006), as well as institutional ownership (Charfeddine and Elmarzougui, 2010; Sahut and Gharbi, 2010; Thanatawee, 2014). The measurement of managerial ownership is the number of shares owned by the company manager compared to the number of shares outstanding. Similarly, institutional ownership as investors is the number of shares held by the institution against the total number of shares outstanding. Currently institutional investors have an important role, which has changed dramatically from passive investors to being active in monitoring (Charfeddine and Elmarzougui, 2010). Institutional shareholders are usually in the form of entities such as banking, insurance, retire funds and mutual funds. Institutional investors have the capability to analyze financial statements directly compared to individual investors.

Another proxy in corporate governance is the existence of an independent commissioner. It is the number of independent commissioners to the total board of commissioners owned by the company. Research (Indriawati and Sari, 2017) examined the effect of independent commissioners on voluntary disclosure. The audit committee also has an important role in creating GCG because it is able to monitor the process of financial statements (Almaqoushi and 
Powell, 2017). Research related to the audit committee with the value of the company has also been carried out by Alqatamin (2018), Chan and Li (2008).

\subsection{Corporate Social Responsibility (CSR)}

CSR in Indonesia is a mandate that must be implemented, but the reality is not yet fully implemented by the company. CSR awareness is only owned by companies that are committed to building a better quality of life together for all stakeholders and the environment. According to Behringer and Szegedi (2016) companies must offer the creation of a balance amongs economic interests, environmental needs and social expectations by conducting CSR as a business model to integrate the spirit of sustainable development.

Research (Singh et al., 2011) used 6 dimensions of CSR based on the international CSR index such as the Dow Jones corporate sustainability index and the FTSE4 Good index in evaluating the impact of CSR on stock market value. These dimensions are CSR practices that focus on community investment, workplace quality, CSR and reporting strategies, stakeholder agreements, environmental performance and supply chains. Many studies have been conducted to examine how the influence of CSR on corporate value. The results vary between studies. Some proved that the relationship is positive, partly negative, and others proved neutral (Hafez, 2016). Hafez (2016) research proves that there is no significant influence between CSR on company value. However, there is a significant influence between CSR on the company's financial performance. The CSR index is used based on the principles of CSR in the OECD which consists of 9 questionnaires with scores ranging from 0 to 10 for each question.

The effect of social disclosure of company activities on company value (Dagilienè, 2013) means additional costs. Companies that report low social responsibility, actually have high corporate value as measured by market to book value.

\section{Research Method}

This research was conducted using a descriptive quantitative approach, where the population is companies listed in the LQ-45 index on the Indonesia Stock Exchange. The stocks included in this LQ45 index are those that have the largest market capitalization and a high level of trading liquidity. Purposive sampling is used to determine the sample and selected as many as 15 companies. Observation period from 2014-2017.

The analysis technique used is the panel data regression model, with the dependent variable (Y) is the market price to book value ratio (PBV) as the company's value (Hafez, 2016). PBV is the ratio of market price per share to book value per share. While the independent variable used in this study is GCG which is represented by four variables, namely managerial ownership / MO (X1), institutional ownership / IO (X2), independent commissioner / IC (X3), and Audit committee / AC (X4). Another variable to see its effect on the value of the company is CSR as $\mathrm{X} 5$. The panel regression model is as follows;

Where:

$$
Y_{i t}=\alpha+\beta_{1} X_{1 i t}+\beta_{2} X_{2 i t}+\beta_{3} X_{3 i t}+\beta_{4} X_{4 i t}+\beta_{5} X_{5 i t}+e_{i t}
$$

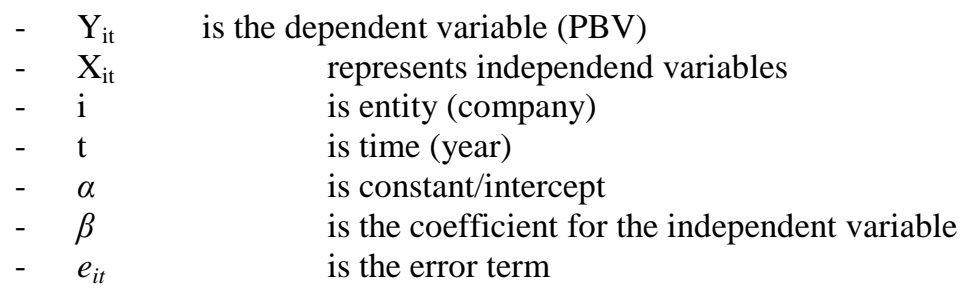

Either managerial ownership (MO) or institutional ownership (IO) is a ratio of the number of each ownership to the total number of shares outstanding. Independent commissioners (IC) are the ratio between the numbers of IC to the number of commissioners. The Audit Committee (AC) is the number of members of the company's audit committee.

For the measurement of CSR performance in this study, the content analysis method is used by looking at whether there is a report / information on social activities carried out by the company. It is given a score of 1 if there are reports, and 0 if there are no reports. There are 79 items of CSR disclosure guidelines issued by the Global Reporting Initiative (Gunawan, 2009) which are divided into 6 indicators, namely economic indicators, environmental and social performance (employment, human rights, society and product responsibility).

In panel data analysis, classical assumptions were tested, namely multicollinearity test and heteroscedasticity test. To estimate the data panel model is used ordinary least square (common effect), fixed effec model (FEM) and random effect model (REM). For selecting the best estimation model (Akbar et al., 2011) conducted a chow test, Haussman test, and Breusch-Pagan Lagrange Multiplier test.

\section{Data Analysis and Discussion \\ 4.1. Panel Data Analysis}

To estimate the model parameters using panel data, the first Chow Test is performed. This test is used to determine whether panel data regression techniques with fixed effect methods are better than the common effect method. The result is in table 1, showing cross-section chi-square is significant with $\mathrm{P}$ value of 0.000 which means the fixed effect method is selected. 
Table-1. Chow Test Result

\begin{tabular}{l|l|l}
\hline Effects Test & Statistic & Prob \\
\hline Cross-section F & 113.109244 & 0.0000 \\
\hline Cross-section Chi-Square & 222.208695 & 0.0000 \\
\hline
\end{tabular}

The second step is to do the Hausman Test to choose whether the fixed effect model is more suitable than the random effect model. If it receives $\mathrm{H}_{0}$, random effect is selected. If it rejects $\mathrm{H}_{0}$ or accepts $\mathrm{H}_{\mathrm{a}}$, the fixed effect model is chosen. From the results of the Hausman Test is in table 2, shows that $\mathrm{H}_{0}$ is accepted or $\mathrm{p}$ value is $0.682>0.05$. It means the method choosen is random effect.

Table-2. Haussman Test Result

\begin{tabular}{|c|c|c|}
\hline Test Summary & Chi-sq Statistic & Prob \\
\hline Cross-section random & 3.115780 & 0.6821 \\
\hline
\end{tabular}

Third, we continue with the Langrangian Multiplier (LM) test to determine whether to choose random effects or common effects. If receiving $\mathrm{H}_{0}$ means common effect, on the contrary if it accepts $\mathrm{H}_{\mathrm{a}}$ or reject $\mathrm{H}_{0}$ it means random effect. LM Test results in table 3 shows that the $\mathrm{P}$ value in the Pagan Breunch method is $0,000<0.05$, so the best estimation method is random effects or receiving $\mathrm{H}_{\mathrm{a}}$.

\begin{tabular}{l|l|l|l}
\multicolumn{5}{c}{ Table-3. Lagrange Multiplier Test Result } \\
\hline & Test Hypothesis & Both \\
\hline & Cross-section & Time & 71.06512 \\
\hline Breusch-Pagan & 69.28794 & 1.777186 & $(0.0000)$ \\
\hline & $(0.0000)$ & $(0.1825)$ &
\end{tabular}

Without using the three tests above, some econometrics experts usually choose the best method as follows; if the panel data has a number of times ( $t$ ) smaller than the number of individuals (i), it is recommended to use the random effect method. This study has a time (t) of 4 years, smaller than the number of individuals (companies) of 15, which means that this study use the random effect method.

\subsection{Multiple Regression Analysis}

In multiple regression analysis using panel data, not all classical assumption tests were carried out. If the independent variable is more than one, multicollinearity tests need to be carried out, to ensure that there is no relationship between independent variables. The multicollinearity test results are in table 4.

Table-4. Correlation Matrix Result

\begin{tabular}{l|l|l|l|l|l}
\hline & MO & IO & IC & AC & CSR \\
\hline MO & 1.000 & 0.019 & -0.066 & -0.192 & -0.100 \\
\hline IO & 0.019 & 1.000 & 0.030 & -0.170 & -0.105 \\
\hline IC & -0.066 & 0.030 & 1.000 & 0.073 & 0.137 \\
\hline AC & -0.192 & -0.170 & 0.073 & 1.000 & 0.073 \\
\hline CSR & -0.100 & -0.105 & 0.137 & 0.073 & 1.000 \\
\hline
\end{tabular}

From table 4, it can be seen that the multicollinearity test results have no correlation between independent variables where the matrix correlation value does not exceed 0.8. Another assumption that needs to be done in the regression analysis with panel data is the heteroscedasticity test, there is a table 5. There are no symptoms of heteroscedasticity in this study, as seen from the P-value of Obs*R-squared is greater than 0.05 .

Table-5. Heteroscedasticity Test Result

\begin{tabular}{l|l|l|l}
\hline Heteroskedasticity Test: White & \\
\hline F-statistic & 1.560848 & Prob. F(5,54) & 0.1868 \\
\hline Obs*R-squared & 7.576411 & Prob. Chi-Square(5) & 0.1812 \\
\hline Scaled explained SS & 42.51170 & Prob. Chi-Square(5) & 0.0000 \\
\hline
\end{tabular}

The results of multiple regressions with random effect models are shown in table 6. The multiple determination coefficient value shown by adjusted R-squared is 0.597953 which means that the contribution of independent variables in this model is able to explain the dependent variable of 59.79 percent. Meanwhile, the remaining 40.21 percent is explained by other variables not included in this study. 
Table-6. The result of $\mathrm{F}$ test, adjusted R-squared and $\mathrm{T}$ test

\begin{tabular}{l|l|l|l}
\hline Variable & Regression coefficients (B) & t-test & Signification \\
\hline Constants & 8.093181 & 0.869117 & 0.3886 \\
\hline MO & -6.528671 & -0.769987 & 0.4447 \\
\hline IO & -0.090519 & -0.188475 & 0.8512 \\
\hline IC & -29.65509 & -8.573265 & $0.0000 * *$ \\
\hline AC & -0.377110 & -0.632806 & 0.5295 \\
\hline CSR & 35.23768 & 1.786496 & $0.0796 *$ \\
\hline Adjusted R ${ }^{2}$ & $=$ & & 0.597953 \\
\hline F-statistic & $=$ & & 18.54980 \\
\hline Prob & $=$ & & 0.000000 \\
**significant at level of 5\% &
\end{tabular}

The F-statistic value in this model is 18,549 with $\mathrm{P}$-value $0,000<0.05$ which can be concluded that independent variables simultaneously affect significantly independent variables. The equation of the multiple regression models that is formed is as follows;

$$
\mathrm{Y}=8,093-6,529 \mathrm{X} 1-0,090 \mathrm{X} 2-29,655 \mathrm{X} 3-0,377 \mathrm{X} 4+35,237 \mathrm{X} 5
$$

Partially, the independent variable that influences is $\mathrm{X} 3$ or independent commissionaries (IC) with a P-value of $0.000<0.05$ with a significant level of $\alpha=5 \%$. This means that the IC variable has a partial effect on the firm value. IC regression coefficient value is -29.65509 , which means that if other independent variables are constant, there is a negative influence on the firm value where each increase in IC by 1 point will reduce the firm value as many as 29.65. The influence of IC is significantly on the firm value, in line with research (Jensen and Meckling, 1976) but with the opposite direction. Jensen and Meckling (1976), explained that the existence of IC is needed to control and supervise management performance so as to create good corporate governance. Good corporate governance has a positive effect on the firm value. Conversely, the influence of IC in this study has a negative effect on firm value. In Indonesia, it becomes an anomaly case because the existence of IC in companies are alleged only as entrusted positions related to interests. So that the existence of IC in a company is burdensome instead, because the function of monitoring and controlling of management is weak. The more independent commisioners, the lower firm value because they do not encourage good corporate governance. Research (Indriawati and Sari, 2017) proves that the existence of IC in Indonesia does not influence on the information disclosure.

Another independent variable that has a partial effect on the firm value is CSR with a significance level of $10 \%$. The P-value for CSR is $0.07<0.1$. The value of CSR regression coefficient is 35.23768 , which means that if any an increase of 1 point of CSR there will increase the firm value as many as 35.23768. The results of studies on CSR are varied. CSR and firm value have a positive relationship, if CSR activities are aligned with the company's reputation (Servaes and Tamayo, 2013). Empirical research conducted by Hafez (2016) reveals that CSR does not negatively affect the firm value, but provides a positive influence on financial performance. On the contrary (Dagilienė, 2013) found that companies with the highest PVB value were far from socially accountable.

Other independent variables such as managerial ownership, Independent ownership, and Auditor committee each have no partial effect on the value of the company because P-value is greater than $\alpha=5 \%$ or $\alpha=10 \%$. Managerial ownership (MO) has a P-value of $0.444>0,000$, which means that there is no influence between MO and firm value. This research is in line with (Lee and Hwang, 2012) who stated that there is no positive or negative influence between managerial ownership and firm value.

Institutional ownership (IO) produces a p-value of 0.8512 which means there is no influence of IO on the firm value. Conversely, research (Charfeddine and Elmarzougui, 2010) found that there was a negative influence on the company's performance as a proxy of Tobin's Q. IO is assumed not to play a role in monitoring and controlling efficient governance activities in the company so that it does not contribute to the company's performance. In this study, although the IO does not have a significant effect, it has the same negative coefficient trend as the research by Charfeddine and Elmarzougui (2010).

The audit committee (AC) has a p-value of 0.5295 with a coefficient value of -0.387 which means that the negative influence of $\mathrm{AC}$ is not significant to the firm value. If the audit committee rarely holds regular meetings with the parties such as internal and external auditors, board of directors and board of commissioners, then the existence of the audit committee does not have a positive influence on the firm value.

\section{Conclusion}

In this study, the analysis of GCG and CSR on firm value that is proxied by PBV values uses panel data regression with random effect method. Simultaneously, the influence of GCG and CSR on firm value is significant. Partially, independent commissioners have a significant effect on the firm value, despite anomaly. The results of research on CSR are varied so far. In this study proves that CSR by companies listed on the LQ-45 Indonesia Stock Exchange has a significant effect on increasing the firm value.

\section{References}

Akbar, A., Imdadullah, M., Ullah, M. A. and Aslam, M. (2011). Determinants of economic growth in asian countries: A panel data perspective. Pakistan Journal of Social Sciences, 31(1): 145-57. 
Almaqoushi, W. and Powell, R. (2017). Audit committee indices, firm value, and accounting outcomes. SSRN Electron. J.: Available: https://ssm.com/abstract=295718

Alqatamin, R. M. (2018). Audit committee effectiveness and company performance: Evidence from jordan. Accounting Finance Research, 7(2): 48-60.

Behringer, K. and Szegedi, K. (2016). The role of CSR In achieving sustainable development - theoretical approach. European Scientific Journal, 12(22): 10-25.

Cahyandito, M. F. and Pau, O. N. (2017). The importance of considering GCG and CSR while pursuing corporate share value. Journal Bisnis and Manajemen, 18(1): 21-33.

Chan, K. C. and Li, J. (2008). Audit committee and firm value: Evidence on outside top executives as expertindependent directors. Corporate Governance, 16(1): 16-31.

Charfeddine, L. and Elmarzougui, A. (2010). Institutional ownership and firm performance: Evidence from France. The IUP Journal of Behavioral Finance, 7(4): 35-46.

Chen, M. Y. (2006). Managerial ownership and firm performance: an analysis using switching simultaneousequations models. Applied Economics, 38(2): 161-81.

Dagiliené, L. (2013). The influence of corporate social reporting to company's value in a developing economy. Procedia Economics and Finance, 5(2013): 212-21.

Daly, H. (2015). Conflicts of interest in agency theory: A theoretical overview. Global Journal of Human-Social Science Economics, 15(1): 1-7.

Fahlenbrach, R. and Stulz, R. M. (2009). Managerial ownership dynamics and firm value. Journal of Financial Economics, 92(3): 342-61.

Gherghina, S. C. and Vintila, G. (2016). Value: The case of listed companies in Romania. Economics and Sociology, 9(1): 23-42.

Gunawan, J. (2009). Measuring corporate social responsibility performance', national center for sustainability reporting. Available: http://www.ncsr-id.org/2009/09/08/measuring-corporate-social-responsibilityperformance/

Hadiwijaya, T., Lahindah, L. and Pratiwi, I. R. (2016). Effect of capital structure and corporate governance on firm value study of listed banking companies in indonesia stock exchange. Journal of Accounting and Business Studies, 1(1): 39-55.

Hafez, H. M. (2016). Corporate social responsibilty and firm value: An empirical study of an emerging economy. Journal of Governance and Regulation, 5(4): 40-53.

Haryono, U. and Iskandar, R. (2015). Corporate social performance and firm value. International Journal of Business and Management Invention, 4(11): 69-75.

Hatem, B. S. (2015). Interdependence between managerial ownership, leverage and firm value: Theory and empirical validation. International Journal of Economics and Finance, 7(12): 106-18.

Hidayat, A. A. and Utama, S. (2015). Board characteristics and firm performance: Evidence from Indonesia. Int. Res. J. Bus. Stud., 8(3): 137-54.

Ilyas, M. and Rafiq, M. (2012). Impact of corporate governance on perceived organizational success. International Journal of Busioness and Social Science, 3(13): 178-87.

Indriawati, F. and Sari, D. A. P. (2017). Proportion of the independent commissioners' board, institutional ownership and its characteristics effect on discussion of sukarela in annual report empirical study of manufacturing companies listed on BEI (period 2013 - 2015. Research Journal of Finance and Accounting, 8(12): 55-64.

Iwu-Egwuonwu, D. R. C. (2010). Does corporate social responsibility (CSR) impact on firm performance? A literature evidence. SSRN Electron. J.: Available: http://ssm.com/abstract=1659586

Iwuji, C. C., Okeke, O. C., Ezenwoke, B. C., Amadi, C. C. and Nwachukwu, H. (2016). Earth resources exploitation and sustainable development: Geological and engineering perspectives. Engineering, 8(1): 21-33.

Jaimes-Valdez, M. A., Jacobo-Hernandez, C. A. and Ochoa-Jimenez, S. (2017). Corporate governance: International context and trends from 2005 to 2015. International Journal of Business and Management, 12(2): 158-69.

Jallo, A., Mus, A. R. and Mursalim, S. (2017). Effect of corporate social responsibility, good corporate governance and ownership structure on financial performance and firm value: A Study in Jakarta Islamic Index. IOSR Journal of Business and Management, 19(11): 64-75.

Jensen, M. C. and Meckling, W. H. (1976). Theory of the firm: Managerial behavior, agency costs and ownership structure. Journal of Financial Economics, 3(4): 305-60.

Jo, H. and Harjoto, M. A. (2011). Corporate governance and firm value: The impact of corporate social responsibility. Journal of Business Ethics, 103(3): 351-83.

Juniarti, J. (2013). Good corporate governance and predicting financial distress using logistic and probit regression model. Jurnal Akuntansi dan Keuangan, 15(1): 43-50.

Kang, S. B., Li, J. and Sun, J. (2015). Corporate social responsibility and firm value: The role of major customers. 34.

Khan, H., 2011. "A literature review of corporate governance." In International Conference on E-Business, Management and Economics. pp. 1-5.

Kumar, N. (2013). Global financial crisis: Corporate governance failures and lessons. Journal of Finance, Accounting and Management, 4(1): 21-34.

Kurniasari, W., Wibowo, B. J. and Wijaya, Y. A. (2017). The mediating effect of corporate social responsibility and good corporate governance on the company's firm value. Research Journal of Social Science, 10(3): 1-7. 
Lee, M. and Hwang, H. S. (2012). The interaction effects of firm value, managerial ownership retention, earnings forecasts and earnings management. Business and Management Research, 1(2): 94-112.

Manchiraju, H. and Rajgopal, S. (2015). Does corporate social responsibility (csr) create shareholder value? Exogenous shock-based evidence from the indian companies act 2013. SSRN Electron. J.: Available: http://ssrn.com/abstract $=2602960$

Modak, N. M., Panda, S., Sana, S. S. and Basu, M. (2014). Corporate social responsibility, coordination and profit distribution in a dual-channel supply chain. Pacific Science Review, 16(4): 235-49.

Mulyono, M., Suprapto, A. T. and Prihandoko, D. (2018). The effect of corporate governance and firm performance on stock price: An empirical study on Indonesia stock exchange. Binus Business Review, 9(1): 79-85.

Panda, B. and Leepsa, N. M. (2017). Agency theory: Review of theory and evidence on problems and perspectives. Indian Journal of Corporate Governance, 10(1): 74-95.

Pandelaki, K. D. and Farida, F. (2017). The influence of firm fundamental and macroeconomic to stock returns: A case study of listed banking sector in IDX. International Journal of Business and Management, 5(8): 21117.

Ruiz-Mallorquí, M. V. and Santana-Martín, D. J. (2011). Dominant institutional owners and firm value. Journal of Bank and Finance 35(1): 118-29.

Sahut, J. M. and Gharbi, H. O. (2010). Institutional investors' typology and firm performance: The case of french firms. International Journal of Business, 15(1): 33-50.

Sarah, R. (2017). The benefits of good corporate governance to small and medium enterprises (SMEs) in South Africa: A view on top 20 and bottom 20 JSE listed companies. Problem and Perspectives in Management, 15(4): 271-79.

Servaes, H. and Tamayo, A. (2013). The impact of corporate social responsibility on firm value: The role of customer awareness. Management Science, 59(5): 1045-61.

Shleifer, A. and Vishny, R. W. (1997). Survey of corporate governance. Journal of Finance, 52(2): 737-83.

Singh, T., Mehta, S. and Varsha, M. S. (2011). Macroeconomic factors and stock returns: Evidence from taiwan. Journal of Economics and International Finance, 2(4): 217-27.

Thanatawee, Y. (2014). Institutional ownership and firm value in Thailand. Asian Journal of Business and Accounting, 7(2): 1-22.

Türker, D. (2015). Contrasting instrumental views on corporate social responsibility: Short-term versus long-term profit orientation approach. Procedia - Social and Behavioral Science, 207: 568-76. Available: https://www.sciencedirect.com/science/article/pii/S1877042815052611

Vania, H. and Supatmi, S. (2014). The effect of board diversity towards the company value of financial institutions in Indonesia. International Journal of Business and Management Invention, 3(4): 32-41.

Willim, A. P. (2015). Price book value and tobin's q: Which one is better for measure corporate governance? European Journal of Business Management, 7(27): 74-79. 